Supporting Information

\title{
A Self-Mediating Redox Flow Battery: High-Capacity Polychalcogenide-Based Redox Flow Battery Mediated by Inherently Present Redox Shuttles
}

Yucun Zhou, Guangtao Cong, Hongning Chen, Nien-Chu Lai and Yi-Chun Lu*

Electrochemical Energy and Interfaces Laboratory, Department of Mechanical and Automation Engineering, The Chinese University of Hong Kong, Shatin, N.T. 999077, Hong Kong SAR, China

AUTHOR INFORMATION

* Corresponding Author: yichunlu@mae.cuhk.edu.hk 


\section{Experimental Section}

Materials. Ketjen Black EC-600JD (KB) was received from AzkoNobel. Sulfur powder (S, -100 mesh, purified by sublimation, reagent grade), large sulfur particles (S, 99.98\%), selenium powder (Se, -100 mesh, 99.5\%), alumina oxide $\left(\mathrm{Al}_{2} \mathrm{O}_{3}\right.$, nanopowder, $\left.<50 \mathrm{~nm}\right)$, lithium nitrate $\left(\mathrm{LiNO}_{3}\right.$, 99.99\%), lithium bis(trifluoromethane) sulfonamide (LiTFSI, 99.95\%), Polytetrafluoroethylene (PTFE) solution (60\% water solution), Isopropyl alcohol (IPA, 99.7\%), 1,3-dioxolane (DOL), 1,2dimethoxyethane (DME), and tetraethylene glycoldimethyl ether (TEGDME) were received from Sigma-Aldrich. Lithium hydroxide monohydrate $\left(\mathrm{LiOH} \cdot \mathrm{H}_{2} \mathrm{O}, \mathrm{A} . \mathrm{R}.\right)$, germanium oxide $\left(\mathrm{GeO}_{2}, 5 \mathrm{~N}\right)$ and ammonium dihydrogen phosphate $\left(\mathrm{NH}_{4} \mathrm{H}_{2} \mathrm{PO}_{4}\right.$, A. R.) were received from Sinopharm Chemical Reagent Co., Ltd. $\mathrm{LiNO}_{3}$ and LiTFSI were dried overnight under dynamic vacuum in a glass oven (Bü chi, Switzerland) at $110^{\circ} \mathrm{C}$. Lithium foils (thickness of $0.5 \mathrm{~mm}$ ) were received from Shenzhen Meisen Electromechanical Co. Ltd.

Preparation of LAGP solid-state electrolytes. $\mathrm{Li}_{1.5} \mathrm{Al}_{0.5} \mathrm{Ge}_{1.5}\left(\mathrm{PO}_{4}\right)_{3}$ (LAGP) solid-state electrolytes were synthesized by a solid-state reaction method. Specifically, stoichiometric amounts of $\mathrm{LiOH} \cdot \mathrm{H}_{2} \mathrm{O}$ (10 wt $\%$ excess), $\mathrm{Al}_{2} \mathrm{O}_{3}, \mathrm{GeO}_{2}$ and $\mathrm{NH}_{4} \mathrm{H}_{2} \mathrm{PO}_{4}$ were used as the starting materials. The precursors were thoroughly mixed by planetary ball milling at $400 \mathrm{rpm}$ for $12 \mathrm{~h}$ in acetone and then heated at $600{ }^{\circ} \mathrm{C}$ for $2 \mathrm{~h}$. The mixture was then cooled, ball milled and heated at $800{ }^{\circ} \mathrm{C}$ for $6 \mathrm{~h}$. After that, the milling process was repeated, and the obtained powder was dried and pressed into pellets and sintered at $850^{\circ} \mathrm{C}$ for $6 \mathrm{~h}$. 
Preparation of the S-KB composite. The S-KB composite was prepared by the melt-diffusion method. S powder and $\mathrm{KB}$ were mixed at a weight ratio of $22: 1$ and heated at $155^{\circ} \mathrm{C}$ for $6 \mathrm{~h}$ in air. The content of $\mathrm{S}$ in the composite was determined to be $93 \mathrm{wt} \%$ by thermogravimetric analysis.

Preparation and assembly of $\mathrm{Li}-\mathrm{S}$ coin cells. Li-S CR2025 coin cells were assembled using Li foil $(\Phi 16 \mathrm{~mm})$ as the anode, $1 \mathrm{M}$ LiTFSI in DOL-DME $\left(1: 1 \mathrm{v} / \mathrm{v}, 50 \mu \mathrm{L}, 2 \mathrm{wt} \% \mathrm{LiNO}_{3}\right)$ as the electrolyte, Celgard 2325 ( $\Phi 19$ mm, LLC Corp., USA) as the separator, pure S loaded on KB modified carbon paper as the cathode $\left(\Phi 12 \mathrm{~mm}\right.$, S loading $\left.\approx 1 \mathrm{mg} \mathrm{cm}^{-2}\right)$, and blank carbon paper as the cathodic current collector $(\Phi 12 \mathrm{~mm})$. To prepare the KB modified carbon paper, the dispersed IPA solution containing KB and PTFE binder (60\% water solution, Sigma Aldrich, KB:PTFE=4:1 w/w) was coated onto the carbon paper (Shanghai Hesen Co. Ltd., China, HCP020N, thickness=0.2 $\mathrm{mm}$, surface area is $0.14 \mathrm{~m}^{2} \mathrm{~g}^{-1}$ ), followed by drying at $80{ }^{\circ} \mathrm{C}$ overnight (loading of $\mathrm{KB}$ is around $0.5 \mathrm{mg} \mathrm{cm}^{-2}$ ). To prepare the cathode, pure $\mathrm{S}$ powder was firstly dispersed in acetone by sonicating. The suspension was then dropped onto the $\mathrm{KB}$ modified carbon paper and dried at $60{ }^{\circ} \mathrm{C}$ for $5 \mathrm{~h}$.

Preparation of S, Se and S-KB catholytes. For the 38 vol\% S-62 vol\% electrolyte (38S, 779 gS $\mathrm{L}^{-1}$ ), 34 vol\% Se-66 vol\% electrolyte (34Se, $1646 \mathrm{~g}_{\mathrm{Se}} \mathrm{L}^{-1}$ ) and 20 vol\% S-26 vol\% KB-54 vol\% electrolyte (20S-26KB) catholyte, pure S, Se powder and S-KB composite, was mixed with $1 \mathrm{M}$ LiTFSI in DOL-DME (with/without $\left.2 \mathrm{wt} \% \mathrm{LiNO}_{3}\right)$ in the solid : liquid ratio of $1 \mathrm{~g}: 0.8 \mathrm{~mL}(15 \mathrm{~g}$ $\mathrm{S}: 12 \mathrm{~mL}$ electrolyte), $1 \mathrm{~g}: 0.4 \mathrm{~mL}(36 \mathrm{~g} \mathrm{Se}: 14.4 \mathrm{~mL}$ electrolyte) and $1 \mathrm{~g}: 1.21 \mathrm{~mL}(14 \mathrm{~g} \mathrm{~S}-\mathrm{KB}$ : $17 \mathrm{~mL}$ electrolyte), respectively (S: $2.07 \mathrm{~g} \mathrm{~cm}^{-3}$; Se: $4.82 \mathrm{~g} \mathrm{~cm}^{-3} ; \mathrm{KB}: 0.12 \mathrm{~g} \mathrm{~cm}^{-3}$ ). The mixture was then sonicated using the SLPt Cell Disruptor (Branson, USA) for 5 min before cell assembling. 
Preparation and assembly of static $\mathrm{Li}-\mathrm{S} / \mathrm{Se}$ catholyte cells. $\mathrm{Li}-\mathrm{Se} / \mathrm{S}$ static catholyte cells were assembled using the lab-designed cell (Figure S2). Briefly, a piece of Li foil ( $\Phi 16 \mathrm{~mm}$ ) was placed on the stainless-steel negative cell case. Then a piece of glass fiber ( $\Phi 16 \mathrm{~mm}, \mathrm{QMA}$, Whatman) soaked with $1 \mathrm{M}$ LiTFSI in DOL-DME $\left(120 \mu \mathrm{L}, 2 \mathrm{wt} \% \mathrm{LiNO}_{3}\right)$ was added onto the Li foil. A piece of LAGP solid electrolyte $\left(\Phi 16 \mathrm{~mm}\right.$, thickness $\approx 0.2 \mathrm{~mm}$, density $\left.=3.2 \mathrm{~g} \mathrm{~cm}^{-3}\right)$ was placed onto the glass fiber to address the polysulfide/polyselenide shuttling issue and separate the liquid electrolyte in the anode and cathode side. After that, a piece of KB modified carbon paper $(\Phi 12$ $\mathrm{mm}$ ) which was pre-wetted with $30 \mu \mathrm{L}$ blank electrolyte (1 M LiTFSI in DOL-DME) was placed on the LAGP. A $5 \mu \mathrm{L}$ of catholyte ( $38 \mathrm{~S}$ or 34 Se catholyte without $\mathrm{LiNO}_{3}$ ) was placed on the $\mathrm{KB}$ modified carbon paper. Another piece of aluminum foil (12 mm diameter) was placed on the carbon paper as a current collector followed by a stainless-steel spring. Two cell bodies (bottom and top) were separated by a PTFE spacer and sealed by the PTFE O-ring. Loading of active materials were $\approx 2.2 \mathrm{mg} \mathrm{cm}^{-2}$ and $\approx 4 \mathrm{mg} \mathrm{cm}^{-2}$ for the $38 \mathrm{~S}$ and $34 \mathrm{Se}$ catholytes, respectively (double checked by weighting the carbon paper before and after adding the catholyte). The effective reacting area of the cell was $1.13 \mathrm{~cm}^{2}$. The cell assembling process was conducted in an Ar-filled glove box $\left(\mathrm{H}_{2} \mathrm{O}\right.$ $<1.0$ ppm, $\mathrm{O}_{2}<1.0$ ppm, Etelux, China).

Preparation and assembly of flow cells. The configuration of the flow cell is shown in Figure S3. One piece of lithium foil $(0.05 \times 1 \times 4 \mathrm{~cm})$ was attached to a copper $(\mathrm{Cu})$ cell body, which acted as a current collector for the negative electrode. Two Celgard 2325 separators $(2 \times 4.8 \mathrm{~cm})$ were placed on the surface of the lithium foil. Then a piece of graphite felt (Beijing Jinglong TetanTechnology Co. Ltd., China, surface area is $0.08 \mathrm{~m}^{2} \mathrm{~g}^{-1}, 0.2 \times 1 \times 4 \mathrm{~cm}$ ) and carbon paper 
$(0.02 \times 1 \times 4 \mathrm{~cm})$ acting as electroactive zones for the cathodic reaction were placed on the separator. A PTFE spacer with flow channel $(0.5 \times 1 \times 4.5 \mathrm{~cm})$ was placed between the $\mathrm{Cu}$ cell body and aluminum $(\mathrm{Al})$ cell body. Two piece of small graphite felts $(0.5 \times 1 \times 0.6 \mathrm{~cm})$ connecting the Al cell body and the cathode were pressed onto both ends of the carbon paper. Catholytes (pure $\mathrm{S}$, Se powder or $\mathrm{S}-\mathrm{KB}$ composite suspended in $1 \mathrm{M}$ LiTFSI in DOL-DME, $2 \mathrm{wt} \% \mathrm{LiNO}_{3}$ ) were injected into the channel by a peristaltic pump (Cole Parmer, 7528-20) and flow back to a storage tank in a circular flow. To ensure the homogeneity of the catholyte, a stir bar was added in the tank under continuous stirring. The flow cell assembling process was conducted in the Ar-filled glove box $\left(\mathrm{H}_{2} \mathrm{O}<1.0 \mathrm{ppm}, \mathrm{O}_{2}<1.0 \mathrm{ppm}\right)$. The effective reacting area of the cell was $4 \mathrm{~cm}^{2}$.

Material characterizations. Scanning electron microscopy (SEM) was performed using a JSM7800F field emission scanning electron microscope (JEOL, Japan). X-ray diffraction (XRD) characterization was performed by a SmartLab XRD (Rigaku, Japan) using CuKa radiation. Transmission electron microscopy (TEM) analysis was performed on an FEI Tecnai F20 transmission electron microscope. Carbon papers in the stack and precipitates in the tank for SEM, XRD and TEM characterization were prepared by rinsing the carbon papers/precipitates in DME, and followed by drying. The UV-vis spectra were collected by a SEC2000 UV-Visible spectrophotometer (ALS Co., Ltd., Japan). $140 \mu \mathrm{L}$ catholyte at various discharge-charge depths was taken out from the flow cell and diluted by the blank electrolyte (1 M LiTFSI in DOL-DME, $2 \mathrm{wt} \% \mathrm{LiNO}_{3}$ ) into $700 \mu \mathrm{L}$ for the UV-Vis spectra test. Specific surface areas of the carbon paper and the graphite felt were determined using Brunauer-Emmett-Teller (BET) method with Micromeritics ASAP2020. Viscosity measurements were conducted using Physica MCR 302, 
Anton Paar. The samples were dropped into the measurement gap $(0.5 \mathrm{~mm})$ between two parallel plates (PP25). The viscosity was recorded as a function of the shear rate (increasing) and obtained from the RHEOPLUS software.

Electrochemical characterizations. Galvanostatic discharge/charge tests were performed on a LAND CT2001A battery test system (Wuhan LAND electronics Co., Ltd, China) and a VMP3 electrochemical testing unit (Bio-Logic). Electrochemical impedance spectroscopy (EIS) measurements were performed by using the Bio-Logic with the frequency range of $1 \mathrm{MHz}$ to 0.1 $\mathrm{Hz}$ at an amplitude of $20 \mathrm{mV}$. The calculation of specific discharge/charge capacities is based on the mass of elemental sulfur/selenium.
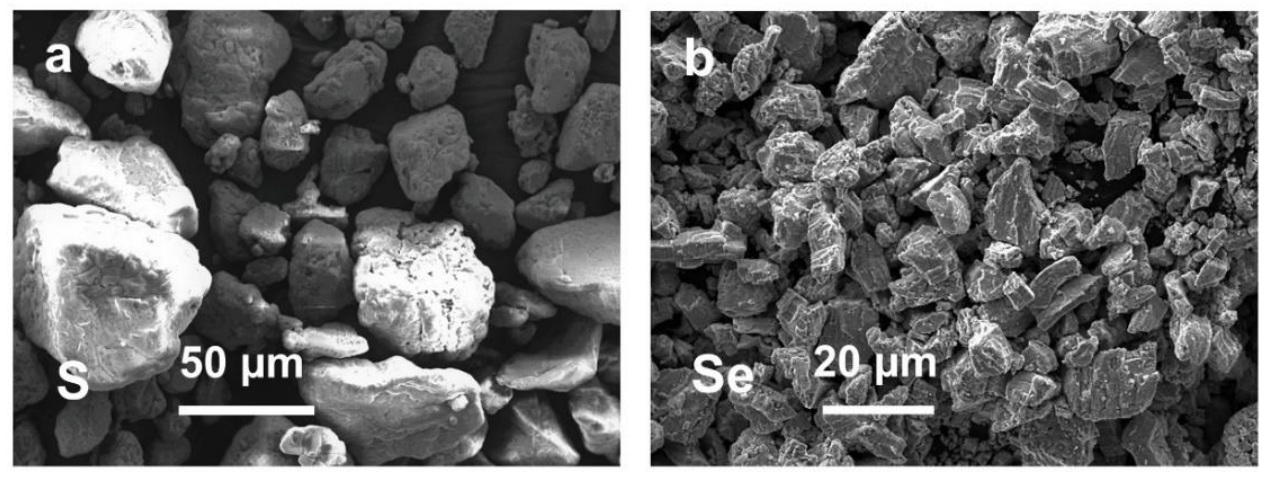

Figure S1. SEM images of S and Se powder. (a) S. (b) Se. 

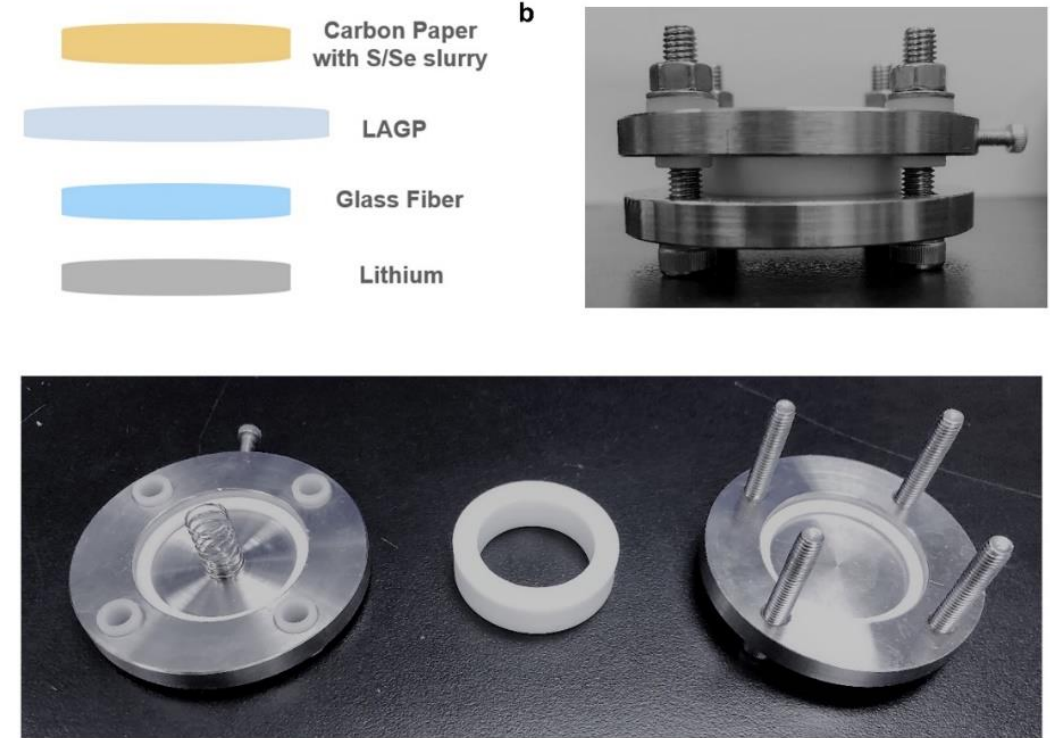

Figure S2. Schematic illustration and photographs of the Li-S/Se catholyte cell for static test. (a) Schematic of the cell. (b) Photograph of the cell (assembled). (c) Photograph of the cell (disassembled). 
Table S1. Comparison of the properties and performances of recent developed flow batteries.

\begin{tabular}{|c|c|c|c|c|c|}
\hline Systems & Solvent & $\begin{array}{l}\text { Theoretical } \\
\text { voltage/ V }\end{array}$ & $\begin{array}{l}\text { Demonstrated } \\
\text { maximum } \\
\text { specific capacity } \\
\left(\mathrm{Ah} \mathrm{L}^{-1}\right)\end{array}$ & $\begin{array}{l}\text { Demonstrated } \\
\text { maximum } \\
\text { volumetric energy } \\
\text { density } \\
\left(\mathrm{Wh} \mathrm{L}^{-1}\right)\end{array}$ & Ref \\
\hline Vanadium & Aqueous & 1.26 & - & 51 & 1 \\
\hline Polysulfide/Iodine & Aqueous & 1.05 & 92 (catholyte) & 43 & 2 \\
\hline Zinc/Iodine-bromide & Aqueous & 1.35 & - & 101 & 3 \\
\hline Alkaline Zinc/Iodine & Aqueous & 1.80 & 194 (catholyte) & 312 (catholyte) & 4 \\
\hline Zinc/Polyiodide & Aqueous & 1.30 & - & 167 (catholyte) & 5 \\
\hline Zinc/Iodine & Aqueous & 1.35 & - & 205 (anolyte) & 6 \\
\hline $\mathrm{TiO}_{2} / \mathrm{LiFePO}_{4}$ & Non-aqueous & 1.65 & 243 (catholyte) & 500 (catholyte) & 7 \\
\hline Lithium/ $/ \mathrm{LiFePO}_{4}$ & Non-aqueous & 3.5 & - & 670 (catholyte) & 8 \\
\hline $\mathrm{Li}_{4} \mathrm{Ti}_{5} \mathrm{O}_{12} / \mathrm{LiCoO}_{2}$ & Non-aqueous & 2.35 & 185 (catholyte) & $300-500$ (estimate) & 9 \\
\hline Lithium/Sulfur & Non-aqueous & 2.2 & 294 (catholyte) & - & 10 \\
\hline Lithium/S-LiI & Non-aqueous & $2.2,3.0$ & 550 (catholyte) & 580 & 11 \\
\hline Lithium/S & Non-aqueous & 2.2 & 1268 (catholyte) & $1137^{*}$ & This work \\
\hline Lithium/Se & Non-aqueous & 2.0 & 1096 (catholyte) & $1062^{*}$ & This work \\
\hline
\end{tabular}

"Energy density was calculated based on the lithium metal anode and catholyte. Theoretical volumetric capacity of lithium is $2061 \mathrm{Ah} \mathrm{L}^{-1}$, utilization of lithium is estimated to be $50 \mathrm{wt} \%$, cell voltage $=2 \mathrm{~V}$. 

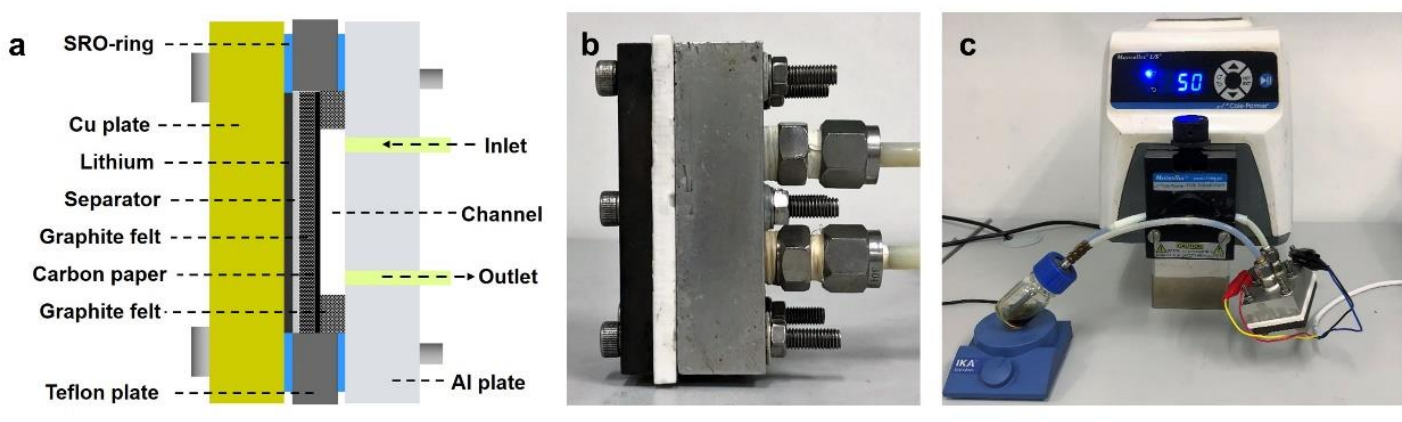

Figure S3. Schematic illustration and photographs of the flow cell. (a) Schematic of the flow cell. (b) Photograph of the flow cell. (c) Photograph of the flow cell under testing.
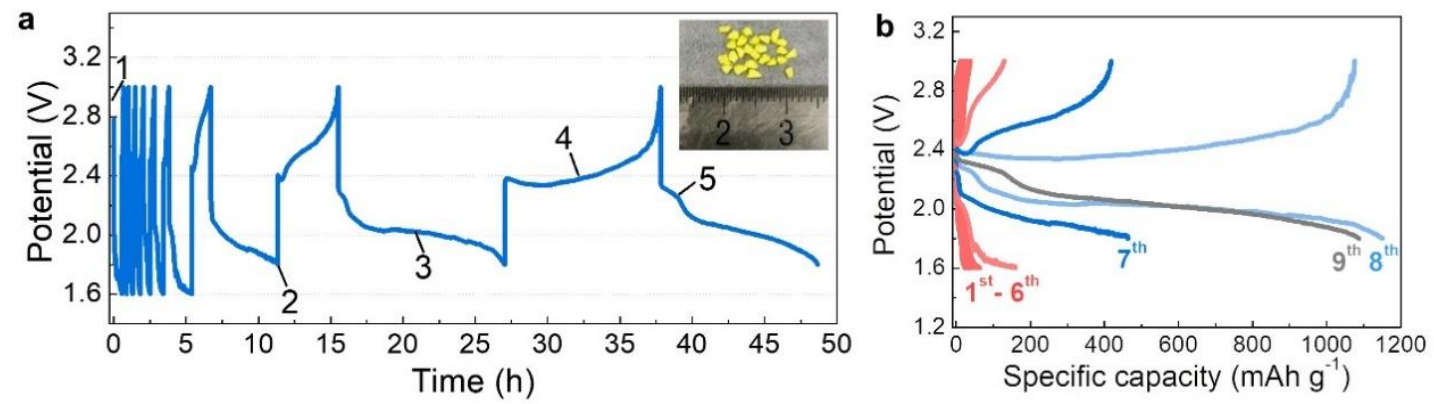

c

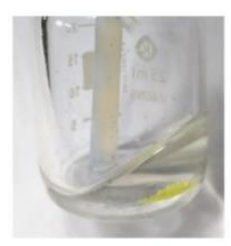

1

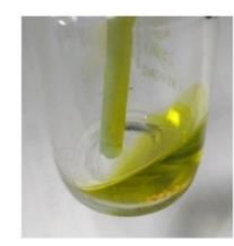

2

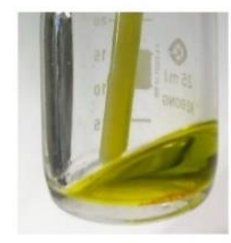

3

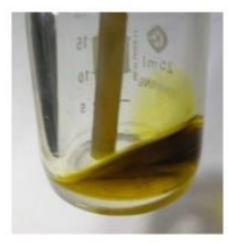

4

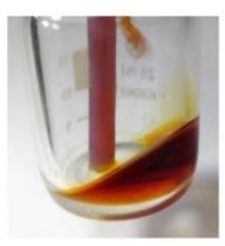

5

Figure S4. Characterization of Li-S flow cells using $40 \mathrm{mg}$ of large $\mathrm{S}$ particles suspended in $10 \mathrm{~mL}$ of an electrolyte as the catholyte. (a) The cell potential as a function of testing time (inset is the photograph of the large S particles). (b) The cell potential as a function of specific capacity. (c) Color changes of the electrolyte in the tank at various discharge-charge depths marked in Figure S4a. The current density was $1 \mathrm{~mA} \mathrm{~cm}^{-2}$, and the flow rate was $6 \mathrm{~mL} \mathrm{~min}^{-1}$. 


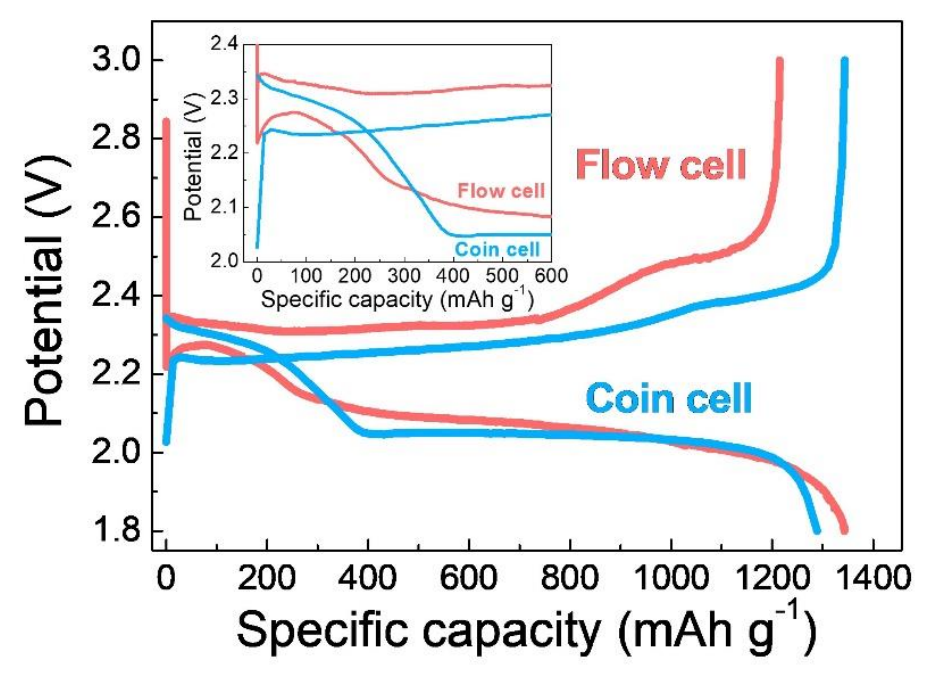

Figure S5. Galvanostatic voltage profiles of the Li-S flow cell and coin cell (first cycle). For the flow cell: 40 $\mathrm{mg}$ of $\mathrm{S}$ powder suspended in $10 \mathrm{~mL}$ of an electrolyte as the catholyte, flow rate was $6 \mathrm{~mL} \mathrm{~min}{ }^{-1}$. For the coin

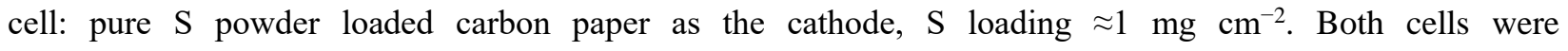
discharged/charged at $\approx 1 \mathrm{~mA} \mathrm{~cm}{ }^{-2}$.

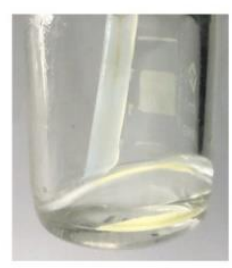

0

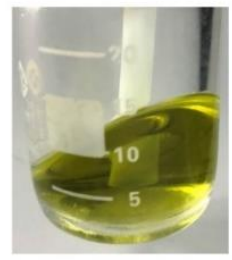

5

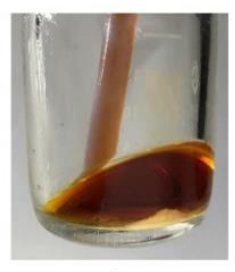

1

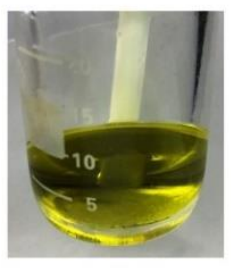

6

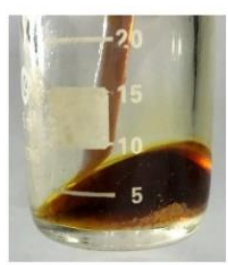

2

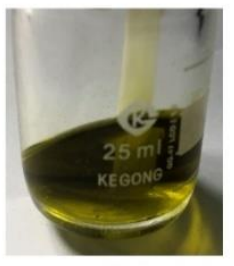

7

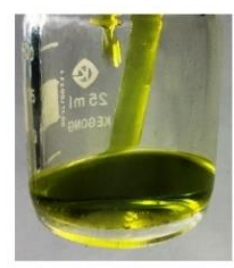

3

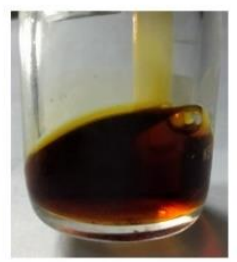

8

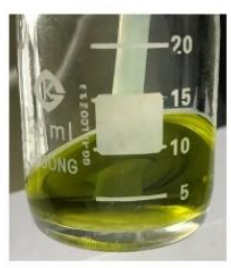

4

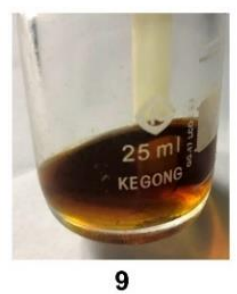

Figure S6. Photographs of the catholyte in the tank at various discharge-charge depths of the Li-S flow cell shown in Figure 3a. 


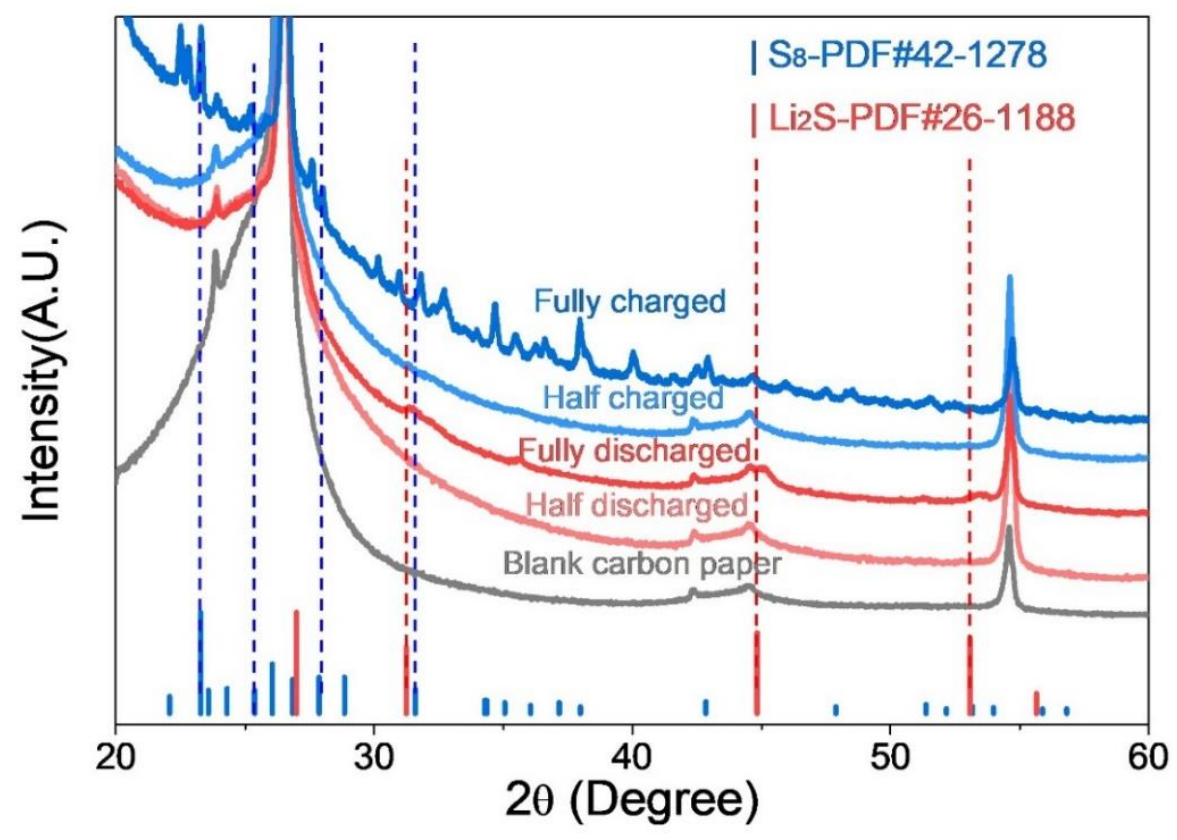

Figure S7. XRD patterns of the carbon paper in the stack of the Li-S flow cells at various discharge-charge depths. The catholyte was $40 \mathrm{mg}$ of S powder suspended in $10 \mathrm{~mL}$ of an electrolyte and the current density was $1 \mathrm{~mA} \mathrm{~cm}{ }^{-2}$. The flow rate was $6 \mathrm{~mL} \mathrm{~min}^{-1}$.

\section{Supplementary discussion for Figure S8:}

To understand if the formation of solid products in the carbon paper electrode would limit the achievable capacity of the flow battery, we further increase the total S loading from $40 \mathrm{mg}$ to 80 $\mathrm{mg}$ in the electrolyte, which could correspond to a high $\mathrm{S}$ loading $\left(20 \mathrm{mg} \mathrm{cm}^{-2}\right)$ on the carbon electrode if all the solid products are deposited onto the carbon paper. As shown in Figure S8b, a high discharge capacity of $1271 \mathrm{~mA} \mathrm{~h} \mathrm{~g}^{-1}$ can be achieved (76\% utilization), which is comparable to that achieved at the loading of $10 \mathrm{mg} \mathrm{cm}^{-2}\left(1343 \mathrm{~mA} \mathrm{~h} \mathrm{~g}^{-1}\right.$, Figure 3a). More interestingly, solid precipitates are clearly observed in both carbon paper and the tank at the end of the discharge process (Figures S8c,d,e,f) with the size ranging from hundreds of micrometers to several 
millimeters. The formation of large flakes (instead of passivation coatings) as discharge product in the electrode and in the tank allows continuous operation of the self-mediating $\mathrm{S}$ flow battery. The ratio of solid particles deposited on the carbon skeleton versus aggregated in tank can be quantified by weighting the precipitates collected in the tank and the carbon paper.

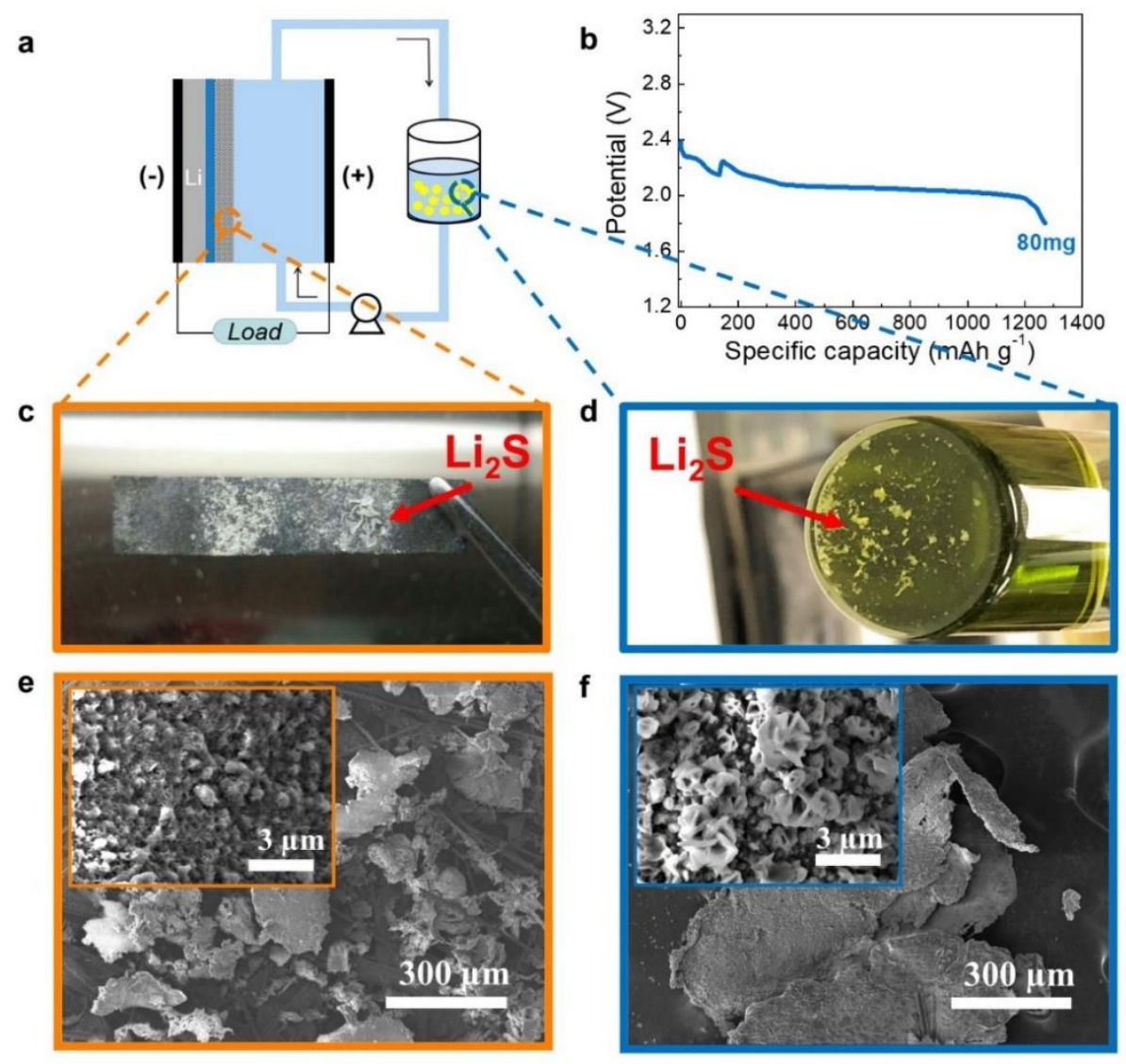

Figure S8. Characterization of Li-S flow cells using $80 \mathrm{mg}$ of $\mathrm{S}$ powder suspended in $10 \mathrm{~mL}$ of an electrolyte as the catholyte. (a) The schematic of the flow cell. (b) Galvanostatic voltage profiles of the Li-S flow cell (1 $\left.\mathrm{mA} \mathrm{cm}{ }^{-2}\right)$. (c) The photograph of the carbon paper in the stack at the end of the first discharge process $(1.8 \mathrm{~V})$. (d) The photograph of the tank at the end of the first discharge process. (e) SEM images of the precipitates on the carbon paper shown in Figure S8c. (f) SEM images of the precipitates in the tank shown in Figure S8d. The flow rate was $6 \mathrm{~mL} \mathrm{~min}^{-1}$. 


\section{Supplementary discussion for Figure S9:}

Figure S9a shows the galvanostatic voltage profiles of a Li-Se flow battery using the carbon-free pure Se catholyte (40 mg Se powder suspended in $10 \mathrm{~mL}$ electrolyte) at $0.5 \mathrm{~mA} \mathrm{~cm}{ }^{-2}$ and $6 \mathrm{~mL}$ $\min ^{-1}$. Benefitting from the self-mediation of polyselenides, the flow cell delivers a high specific capacity of $660 \mathrm{mAh} \mathrm{g}^{-1}$, corresponding to a $97 \%$ utilization of Se (Figure S9a). Microsized $\mathrm{Li}_{2} \mathrm{Se}$ agglomerates composed of microflakes are identified at the end of discharge by XRD and SEM characterizations (Figures S9b,c,d).
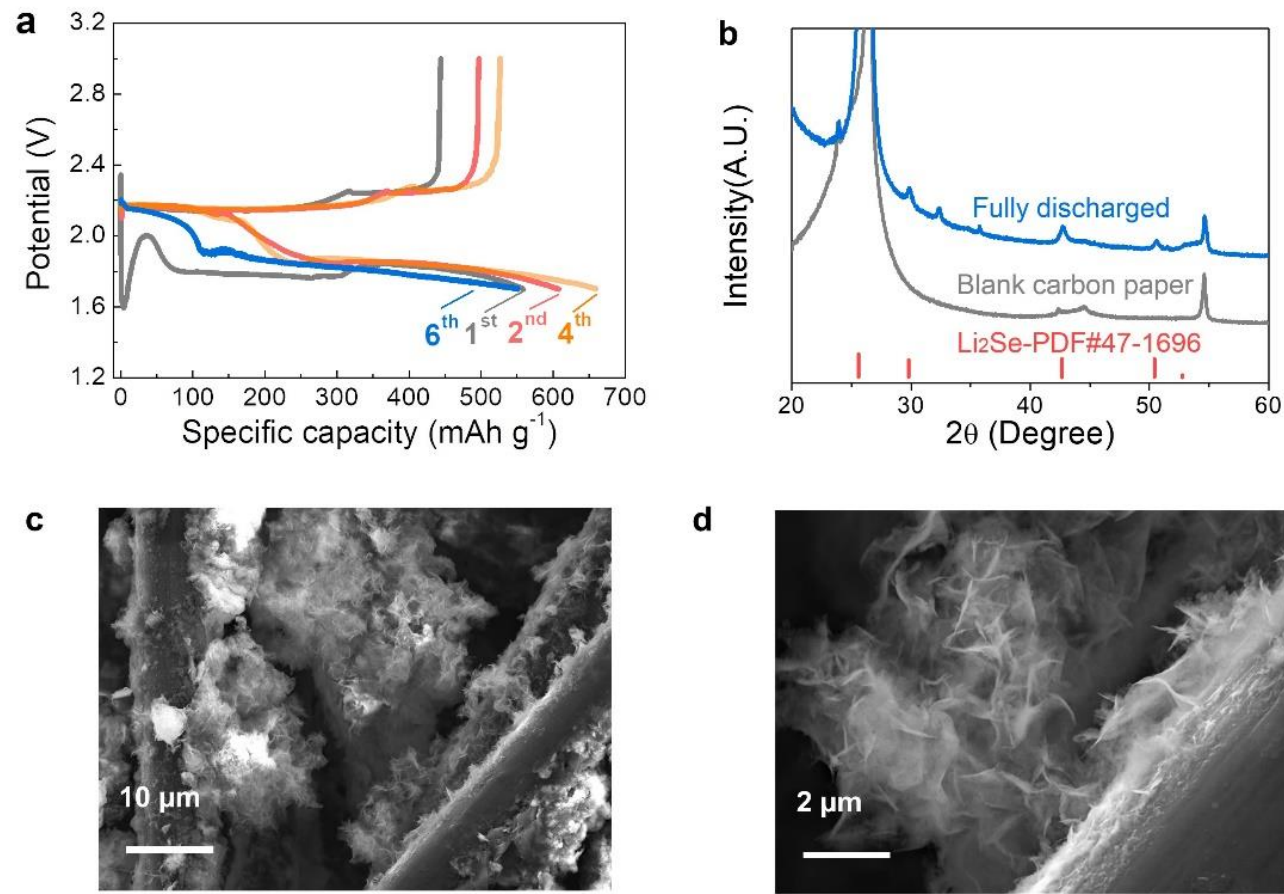

d

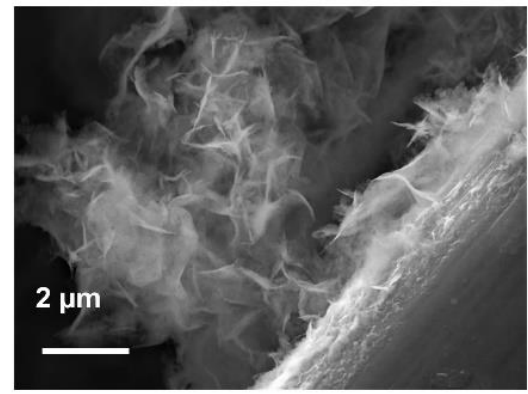

Figure S9. Characterization of Li-Se flow cells using $40 \mathrm{mg}$ of Se powder suspended in $10 \mathrm{~mL}$ of an electrolyte as the catholyte. (a) Galvanostatic voltage profiles of the $\mathrm{Li}-\mathrm{Se}$ flow cell $\left(0.5 \mathrm{~mA} \mathrm{~cm}{ }^{-2}\right)$. (b) XRD patterns of the carbon paper in the stack at the end of the first discharge process. (c)(d) SEM images of the carbon paper in the stack at the end of the $6^{\text {th }}$ discharge process $(1.7 \mathrm{~V})$. The flow rate was $6 \mathrm{~mL} \mathrm{~min}^{-1}$. 


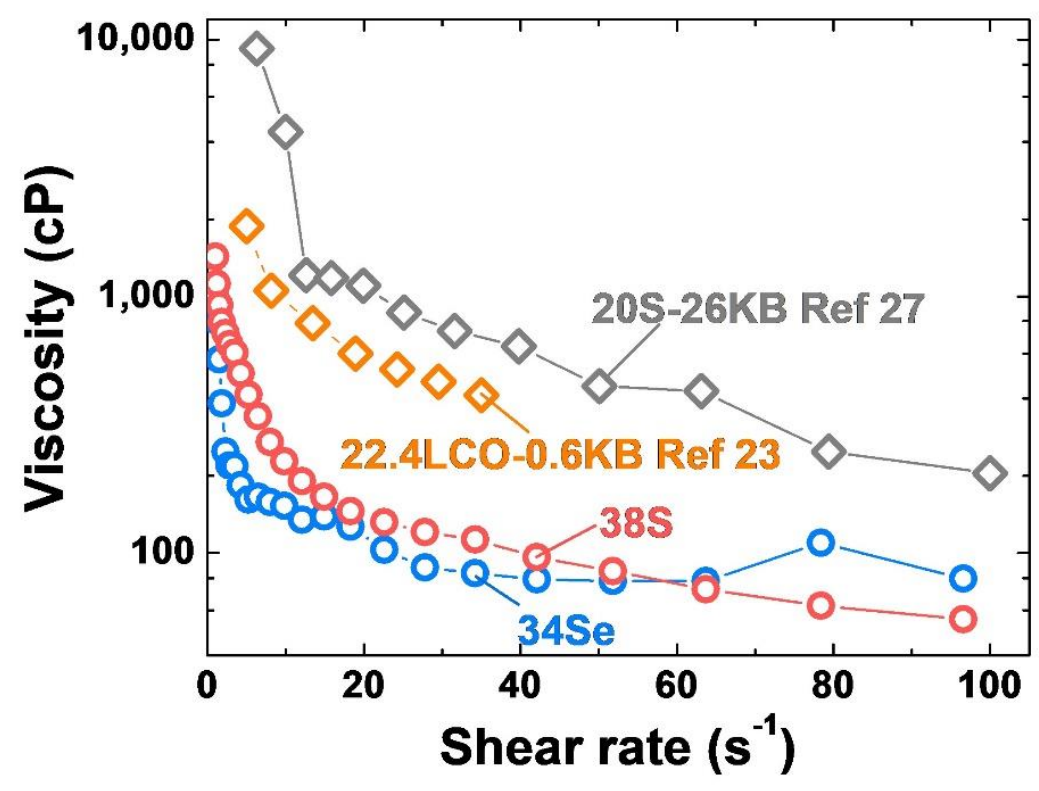

Figure S10. Viscosity versus shear rate of 38S, 34Se, 20S-26KB and 22.4LCO-0.6KB catholytes.

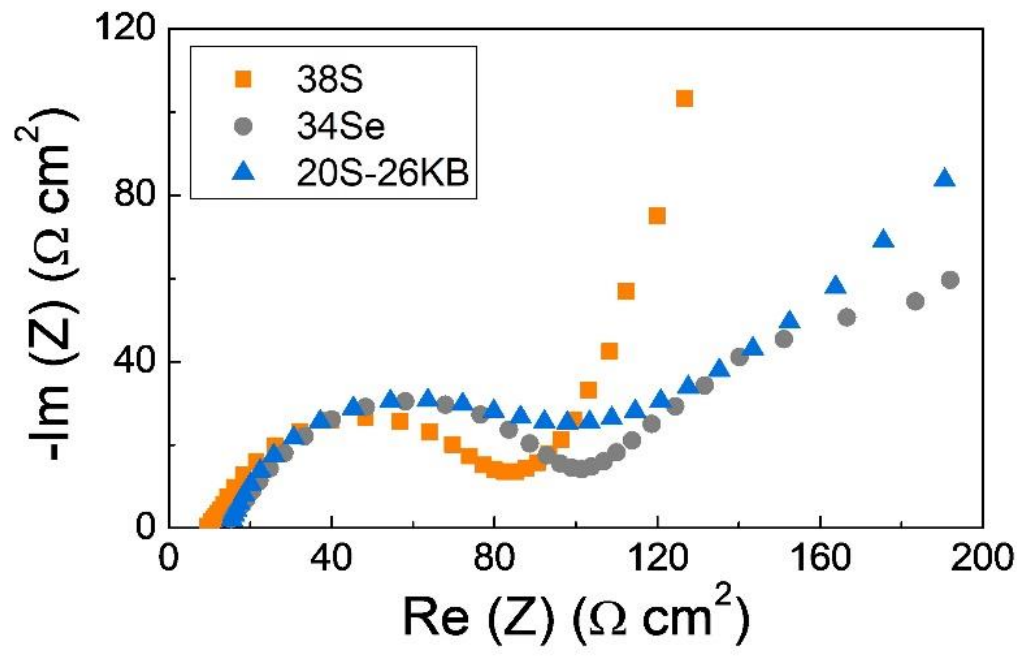

Figure S11. EIS of the flow cells using $38 \mathrm{~S}, 34 \mathrm{Se}$ and $20 \mathrm{~S}-26 \mathrm{~KB}$ as the catholyte, respectively. EIS was measured at OCVs under the continuous flow mode $\left(6 \mathrm{~mL} \mathrm{~min}^{-1}\right)$. 


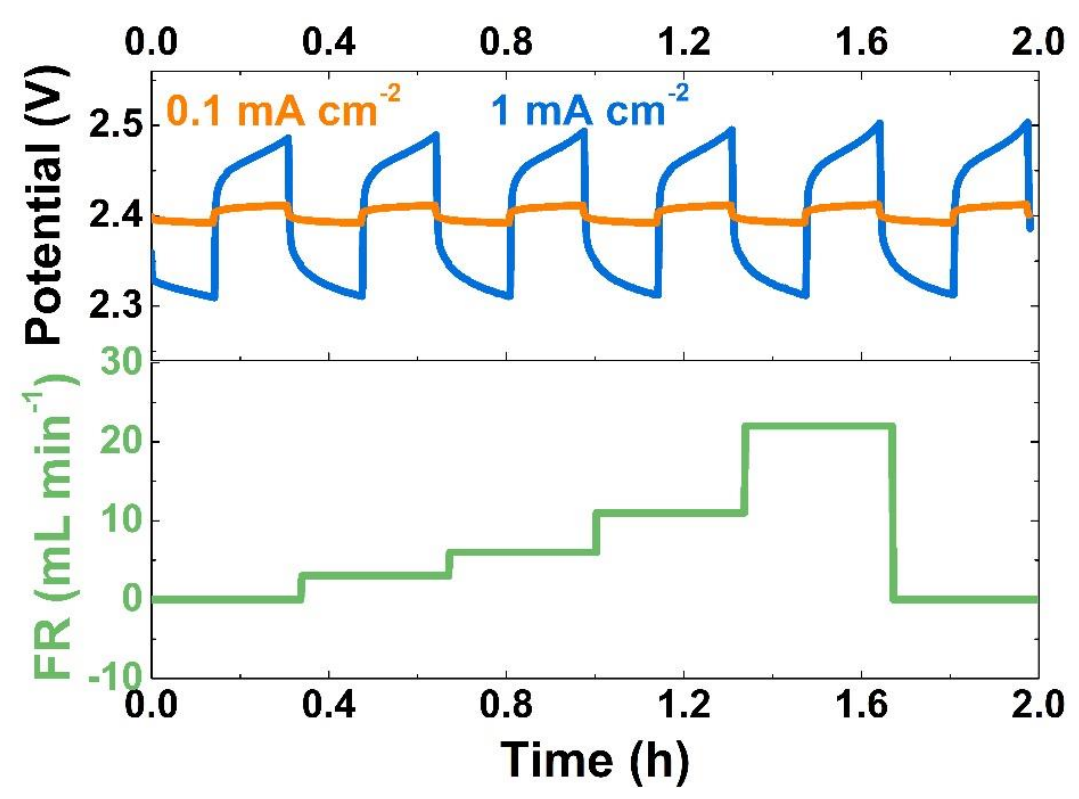

Figure S12. Galvanostatic voltage profiles of the Li-S flow cell at various flow rates (50 mg of S powder suspended in $4 \mathrm{~mL}$ of an electrolyte as the catholyte).

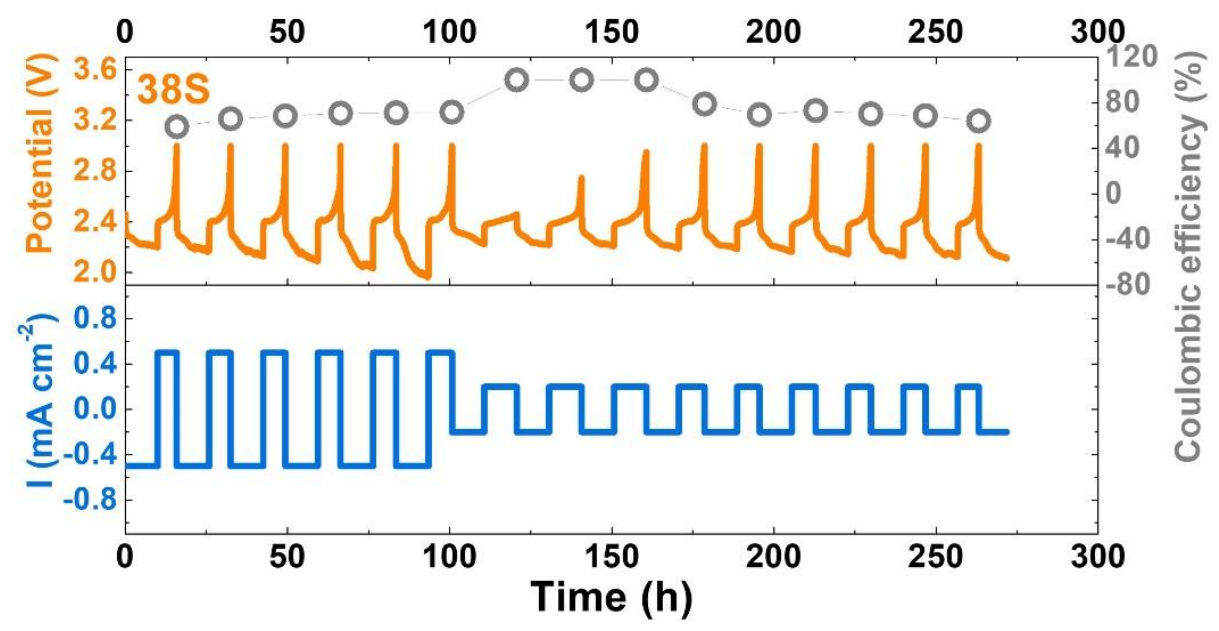

Figure S13. Long-term galvanostatic cycling test of the Li-S flow cell using $38 \mathrm{~S}$ as the catholyte at 0.5 and 0.2 $\mathrm{mA} \mathrm{cm}{ }^{-2}$ (flow rate was $6 \mathrm{~mL} \mathrm{~min}^{-1}$ ). 
Table S2. Estimation of the material cost of our $\mathrm{Li}^{-} \mathrm{S}$ flow battery, state-of-the-art all-vanadium redox flow battery (VRB), and lithium-ion battery systems.

\begin{tabular}{|c|c|c|c|c|c|c|}
\hline Battery system & $\begin{array}{l}\text { Anode price* } \\
\left(\$ \mathrm{~kg}^{-1}\right)\end{array}$ & $\begin{array}{l}\text { Electrolyte } \\
\text { price } \\
\left(\$ \mathrm{~kg}^{-1}\right)\end{array}$ & $\begin{array}{l}\text { Cathode } \\
\text { price* } \\
\left(\$ \mathrm{~kg}^{-1}\right)\end{array}$ & $\begin{array}{l}\text { Cell } \\
\text { voltage } \\
(\mathrm{V})\end{array}$ & $\begin{array}{l}\text { Total cost } \\
\left(\$ \mathrm{kWh}^{-1}\right)\end{array}$ & $\begin{array}{l}\text { Total cost } \\
\text { from } \\
\text { reference } \\
\left(\$ \mathrm{kWh}^{-1}\right)\end{array}$ \\
\hline $\mathrm{Li}-\mathrm{S}$ flow & 65 (Li metal) & 12 & $0.3(\mathrm{~S})$ & 2.0 & 21 (this work) & - \\
\hline VRB & $24\left(\mathrm{~V}_{2} \mathrm{O}_{5}\right)$ & - & $\begin{array}{l}24 \\
\left(\mathrm{~V}_{2} \mathrm{O}_{5}\right)\end{array}$ & 1.25 & ${ }_{2}^{155}\left(\mathrm{~V}_{2} \mathrm{O}_{5}\right.$ only $)$ & $\begin{array}{l}50-110^{12} \\
50-372^{13}\end{array}$ \\
\hline Graphite $-\mathrm{LiFePO}_{4}$ & 9.8 & 5 & 6.3 & 3.2 & 32 & $\begin{array}{l}\sim 50^{14} \\
\sim 56^{15}\end{array}$ \\
\hline Graphite- $\mathrm{LiNi}_{0.6} \mathrm{Co} 0.2 \mathrm{Mn}_{0.2} \mathrm{O}_{2}$ & 9.8 & 5 & 19.8 & 3.6 & 52 & $\begin{array}{l}\sim 55^{14} \\
\sim 62^{16}\end{array}$ \\
\hline
\end{tabular}

"The prices are adopted from www.alibaba.com, https://www.energytrend.cn/news/20190826-74769.html, and

Refs $14-19$ for references ${ }^{14-19}$.

Specific capacity of active materials for calculation (taken utilization into consideration): Lithium metal: 2000 mAh g ${ }^{-1}$ (theoretical: $3860 \mathrm{mAh} \mathrm{g}^{-1}$ ); Sulfur: $1000 \mathrm{mAh} \mathrm{g}^{-1}$ (theoretical: $1675 \mathrm{mAh} \mathrm{g}{ }^{-1}$ ); Graphite: $300 \mathrm{mAh}$ $\mathrm{g}^{-1}$ (theoretical: $372 \mathrm{mAh} \mathrm{g}^{-1}$ ), $\mathrm{LiFePO}_{4}: 140 \mathrm{mAh} \mathrm{g}^{-1}$ (theoretical: $170 \mathrm{mAh} \mathrm{g}^{-1}$ ), $\mathrm{LiNi}_{0.6} \mathrm{Co}_{0.2} \mathrm{Mn}_{0.2} \mathrm{O}_{2}: 160 \mathrm{mAh}$ $\mathrm{g}^{-1}$ (theoretical: $277 \mathrm{mAh} \mathrm{g}^{-1}$ ). Concentration of the active materials: For the $\mathrm{Li}^{-} \mathrm{S}$ flow battery using 38 vol\% $\mathrm{S}-62 \mathrm{vol} \%$ electrolyte (38S), solid S powder : liquid electrolyte ratio=1 $\mathrm{g}: 0.8 \mathrm{~mL}$, assuming the nonaqueous electrolyte' density is $1 \mathrm{~g} \mathrm{~cm}^{-3}$, then solid S powder : liquid electrolyte ratio=1 $\mathrm{g}: 0.8 \mathrm{~g}$; for the lithium-ion battery, the electrolyte to capacity ratio is $5.0 \mathrm{~g} \mathrm{Ah}^{-1}$ (by the industry consensus and also Ref 20) ${ }^{20}$. Only the electrolyte (solvent+salt), active anode and cathode materials are taken into consideration. Note that the price of current collector ( $\mathrm{Cu}$ foil and $\mathrm{Al}$ foil), binder and conducting agent are not considered here, which may further increase the cost of lithium-ion batteries. The rapid drop in price (60\%) of LFP in the market from the year (2018) to this year leads to the lower cost of our estimation compared with the references.

Here is an example how the estimation is calculated 
For our Li-S flow battery:

$$
\frac{1000 \mathrm{Wh}}{2 \mathrm{~V} \times 2000 \mathrm{Ah} / \mathrm{kg}} \times 65 \$ / \mathrm{kg}+\frac{1000 \mathrm{Wh}}{2 \mathrm{~V} \times 1000 \frac{\mathrm{Ah}}{\mathrm{kg}}} \times 0.8 \times 12 \$ / \mathrm{kg}+\frac{1000 \mathrm{Wh}}{2 V \times 1000 \frac{\mathrm{Ah}}{\mathrm{kg}}} \times 0.3 \$ / \mathrm{kg}=21.2 \$ / \mathrm{kWh}
$$

\section{References}

1. Roe, S.; Menictas, C.; Skyllas-Kazacos, M., A high energy density vanadium redox flow battery with 3 M vanadium electrolyte. Journal of The Electrochemical Society 2016, 163 (1), A5023-A5028.

2. Li, Z.; Weng, G.; Zou, Q.; Cong, G.; Lu, Y.-C., A high-energy and low-cost polysulfide/iodide redox flow battery. Nano Energy 2016, 30, 283-292.

3. Weng, G.-M.; Li, Z.; Cong, G.; Zhou, Y.; Lu, Y.-C., Unlocking the capacity of iodide for highenergy-density zinc/polyiodide and lithium/polyiodide redox flow batteries. Energy Environ. Sci. 2017, 10 (3), 735-741.

4. Xu, S.; Cheng, Y.; Zhang, L.; Zhang, K.; Huo, F.; Zhang, X.; Zhang, S., An effective polysulfides bridgebuilder to enable long-life lithium-sulfur flow batteries. Nano Energy 2018, 51, 113-121.

5. Li, B.; Nie, Z.; Vijayakumar, M.; Li, G.; Liu, J.; Sprenkle, V.; Wang, W., Ambipolar zinc-polyiodide electrolyte for a high-energy density aqueous redox flow battery. Nature communications 2015, 6, 6303.

6. Xie, C.; Liu, Y.; Lu, W.; Zhang, H.; Li, X., Highly stable zinc-iodine single flow batteries with super high energy density for stationary energy storage. Energy \& Environmental Science 2019.

7. Jia, C.; Pan, F.; Zhu, Y. G.; Huang, Q.; Lu, L.; Wang, Q., High-energy density nonaqueous all redox flow lithium battery enabled with a polymeric membrane. Sci. Adv. 2015, 1 (10), e1500886.

8. Huang, Q.; Yang, J.; Ng, C. B.; Jia, C.; Wang, Q., A redox flow lithium battery based on the redox targeting reactions between LiFePO 4 and iodide. Energy \& Environmental Science 2016, 9 (3), 917-921. 9. Duduta, M.; Ho, B.; Wood, V. C.; Limthongkul, P.; Brunini, V. E.; Carter, W. C.; Chiang, Y. M., Semi-Solid lithium rechargeable flow battery. Adv. Energy Mater. 2011, 1 (4), 511-516.

10. Chen, H.; Zou, Q.; Liang, Z.; Liu, H.; Li, Q.; Lu, Y.-C., Sulphur-impregnated flow cathode to enable high-energy-density lithium flow batteries. Nat. Commun. 2015, 6, 5877.

11. Chen, H.; Lu, Y. C., A high-energy-density multiple redox semi-solid-liquid flow battery. $A d v$. Energy Mater. 2016, 6 (8), 1502183.

12. Nguyen, T.; Savinell, R. F., Flow batteries. Electrochem Soc Interface 2010, 19 (3), 54-56.

13. Minke, C.; Turek, T., Materials, system designs and modelling approaches in techno-economic assessment of all-vanadium redox flow batteries-A review. J. Power Sources 2018, 376, 66-81.

14. Wentker, M.; Greenwood, M.; Leker, J., A Bottom-Up Approach to Lithium-Ion Battery Cost Modeling with a Focus on Cathode Active Materials. Energies 2019, 12 (3), 504.

15. Placke, T.; Heckmann, A.; Schmuch, R.; Meister, P.; Beltrop, K.; Winter, M., Perspective on performance, cost, and technical challenges for practical dual-ion batteries. Joule 2018, 2 (12), 25282550 .

16. Schmuch, R.; Wagner, R.; Hörpel, G.; Placke, T.; Winter, M., Performance and cost of materials for lithium-based rechargeable automotive batteries. Nat. Energy 2018, 3 (4), 267.

17. Yang, Y.; Zheng, G.; Cui, Y., A membrane-free lithium/polysulfide semi-liquid battery for largescale energy storage. Energy Environ. Sci. 2013, 6 (5), 1552-1558. 
18. Albertus, P.; Babinec, S.; Litzelman, S.; Newman, A., Status and challenges in enabling the lithium metal electrode for high-energy and low-cost rechargeable batteries. Nat. Energy 2018, 3 (1), 16.

19. Eroglu, D.; Zavadil, K. R.; Gallagher, K. G., Critical link between materials chemistry and cell-level design for high energy density and low cost lithium-sulfur transportation battery. J. Electrochem. Soc. 2015, 162 (6), A982-A990.

20. Liu, J.; Bao, Z.; Cui, Y.; Dufek, E. J.; Goodenough, J. B.; Khalifah, P.; Li, Q.; Liaw, B. Y.; Liu, P.; Manthiram, A., Pathways for practical high-energy long-cycling lithium metal batteries. Nat. Energy 2019, 1. 